\title{
Aplicación de enfoques de análisis y criterios de rotura en ensayos de fatiga y su influencia en la predicción de la vida útil de la capa de rodadura asfáltica en la estructura del pavimento Use of analysis approaches and failure criteria on fatigue tests and their influence to estimate the lifespan of the asphallt surface layer on pavement structures
}

\author{
J. Staub de Melo ${ }^{1 *}$, I. Buzzi Torres *, J. Villena **
}

* Universidade Federal de Santa Catarina, Florianópolis, Santa Catarina, BRAZIL

** Universidade Federal do Paraná, Curitiba, Paraná, BRAZIL

Fecha de Recepción: 28/11/2018

Fecha de Aceptación: 08/04/2019

PAG 268-277

\begin{abstract}
The obtaining of fatigue models of asphalt mixtures, are part of the procedures of advanced characterization of the material and are used for the design of pavements. However, there are several approaches to analysis and failure criteria that can be used. These approaches and criteria may not produce the same models of fatigue, resulting in different thicknesses of the asphalt surface in the pavement structure. This study presents the results of the influence of two approaches of analysis (phenomenological and accumulated dissipated energy) and two criteria of rupture (conventional and Pronk \& Hopman) in obtaining fatigue models of the asphalt mixture, and its repercussion in the estimation of useful life of the asphalt surface in the pavement structure. The results show that the phenomenological approach is more conservative than the accumulated dissipated energy, as well as the Pronk \& Hopman criterion in relation to the conventional criterion, that is, the type of approach and the criterion of rupture adopted will directly affect the final thickness of the projected asphalt surface.
\end{abstract}

Keywords: Asphalt mix, fatigue resistance, analysis approaches, rupture criteria, numerical simulation

Resumen

Obtener los modelos de fatiga de mezclas asfálticas es parte de los procedimientos de caracterización avanzada de este material y los mismos son utilizados para el diseño del pavimento. No obstante, existen diversos enfoques de análisis y criterios de rotura que pueden ser utilizados. Estos enfoques y criterios pueden producir modelos de fatiga diferentes y, en consecuencia, capas asfálticas con espesores diferentes en la estructura del pavimento. Este estudio presenta los resultados de la influencia de dos enfoques de análisis, fenomenológico y de energía disipada acumulada, y dos criterios de rotura, convencional y de Pronk \& Hopman, en la obtención de los modelos de fatiga de la mezcla asfáltica, y su repercusión en la estimación de la vida útil de la capa en la estructura del pavimento. Los resultados muestran que el enfoque fenomenológico es más conservador que el de energía disipada acumulada, como también lo es el criterio de Pronk \& Hopman en relación al criterio convencional, es decir, el tipo de enfoque y el criterio de rotura adoptado repercutirán directamente en el espesor final de la capa diseñada.

Palabras clave: Mezcla de asfalto, resistencia a la fatiga, enfoques de análisis, criterios de rotura, simulación numérica

\section{Introduction}

In general, asphalt pavements do not suffer abrupt or sudden cracks, but rather cumulative functional and structural deteriorations when subjected to dynamic loading. Therefore, it is important to study the origin of these pathological manifestations in order to improve the pavement's mechanical and functional performance (Bernucci et al., 2010).

The fatigue phenomenon is one of these deterioration mechanisms, which consists in subjecting a specific material to cyclic loads with low levels of stress and strain (Khalid, 2000). The repeated and alternate bending in the asphalt wearing course, caused by the dynamic loading of vehicle traffic, produces tensile and compressive stresses in the material, thereby fostering the nucleation and growth of microcracking on the inside that compromise the life cycle as the number of load applications increases (Melo, 2014).

\footnotetext{
${ }^{1}$ Corresponding author:

Universidade Federal de Santa Catarina - Florianópolis-SC, BRASIL

E-mail: joao.victor@ufsc.br
}

In this context, the development of asphalt mixture fatigue models allows predicting the performance of the asphalt wearing course in the pavement structure, in the presence of fatigue cracking; consequently, it offers a more reliable design of the necessary thickness of the layer, based on the traffic volume and the project horizon that the highway should have (Melo, 2014).

However, different tests can be used to define the fatigue strength of an asphalt mixture, which allow adopting different analysis approaches and failure criteria. Some of these tests are: the four-point bending test, two-point bending test, uniaxial tension and compression testing, indirect tensile strength test, etc. (Zeiada, 2012). With regard to analysis approaches and failure criteria, most standards (AASHTO T321, 2014); (EN 12697-24, 2018) specify the phenomenological approach and the conventional failure criterion of $50 \%$ reduction of the material's initial modulus. Nevertheless, this analysis approach and this failure criterion, although widely used in the design of fatigue models, do not provide a detailed description of the material's deterioration mechanisms (Sybilski and Bankowski, 2007). Therefore, different researchers (Ameri et al., 2017); (Shadman and Ziari, 2017); (Pasetto and Baldo, 2017); (Dondi et al., 2013) are applying more mechanistic failure approaches and 
criteria, among which we find those based on dissipated energy.

This paper reports the results of a study addressing the influence of applying different analysis approaches and failure criteria on the asphalt layer's fatigue life and the effect on the estimated life cycle of the asphalt wearing course in the pavement structure.

\section{Materials}

In order to carry out this study, an asphalt mixture was designed at the laboratory, and ten prismatic specimens were obtained $(38.1 \mathrm{~cm} \times 6.35 \mathrm{~cm} \times 5.08 \mathrm{~cm}$ ) for undertaking the fatigue tests and the complex modulus in the four-point bending test. The following materials were used for the design and production of the mixture: asphalt binder, mineral aggregates and dolomitic hydrated lime $\mathrm{CH}-1$, classified as Type II according to (AASHTO M303, 2014).

\subsection{Asphalt Binder}

A conventional asphalt binder with the following properties was used: penetration of 55/10 mm (ASTM D5, 2013); softening point at $50.2^{\circ} \mathrm{C}$ (ASTM D36, 2014); apparent viscosity of 4.12 poise at $135^{\circ} \mathrm{C}, 2.07$ poise at $150^{\circ} \mathrm{C}$ and 0.85 poise at $175^{\circ} \mathrm{C}$ (ASTM D4402, 2015); temperature susceptibility index of -0.92 and Performance
Grade (PG) of 64-22 according to (Table 3) of the standard (AASHTO M320, 2017).

\subsection{Mineral Aggregates}

Mineral aggregates have a basaltic origin and the following properties: $100 \% / 100 \%$ coarse aggregate angularity (ASTM D5821, 2017); 49.18\% fine aggregate angularity (ASTM C1252, 2017); 9.59 flat and elongated particles (ASTM D4791, 2019), 61.2\% clay clods (ASTM T176, 2017); 11.58\% hardness (ASTM C131, 2014); 2.14 soundness (ASTM C88, 2018); absence of poor-quality particles (AASHTO T112, 2017); $2.953 \mathrm{~g} / \mathrm{cm}^{3}, 2.880 \mathrm{~g} / \mathrm{cm}^{3}$, $0.849 \%$ of effective specific gravity, apparent specific gravity, and coarse aggregate absorption, respectively (ASTM C127, 2015); $2.974 \mathrm{~g} / \mathrm{cm}^{3}$ of effective specific gravity of fine aggregate (DNER-ME 084, 1995) and $2.804 \mathrm{~g} / \mathrm{cm}^{3}$ of effective specific gravity of the filler (DNER-ME 085, 1994).

\subsection{Gradation Curve}

The definition of the gradation curve was based on the Superpave method criteria for a nominal maximum size of 19 $\mathrm{mm}$. Thus, the grading curve was made of $56.7 \%$ coarse aggregate (passing the $3 / 4$ " sieve and retained on No. 4 sieve), 37.9 fine aggregate (passing through No. 4 sieve and retained on No. 200 sieve) and 5.4\% filler (passing through No. 200 sieve and retained at the bottom). The filler composition was $3.9 \%$ stone dust and $1.5 \%$ hydrated lime. The grading composition is shown in (Figure 1).
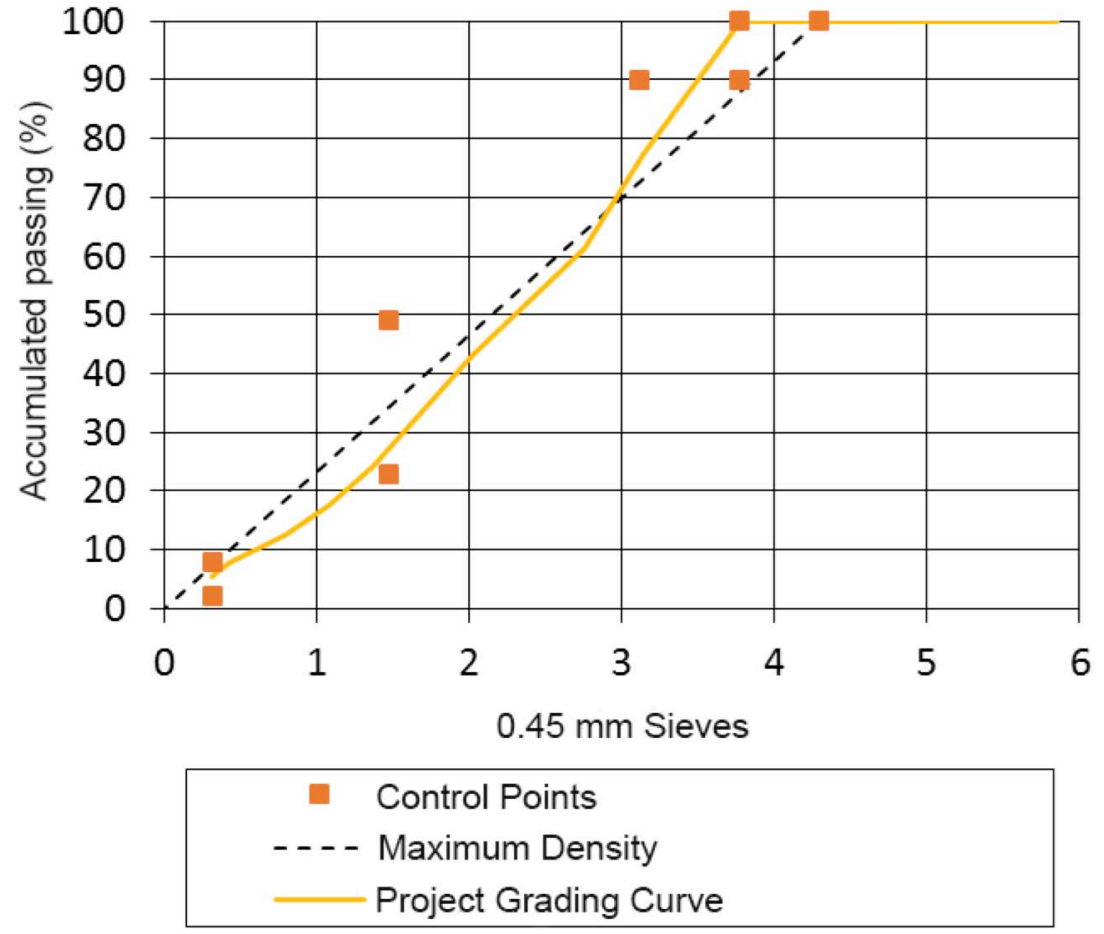

Figure 1. Grading composition of the aggregate mixture 


\subsection{Design of the Asphalt Mixture}

The design of the asphalt mixture was carried out in the Superpave gyratory compactor for heavy traffic volume $\left(N_{\text {initial }}=9\right.$ rotations; $N_{\text {project }}=125$ rotations; $N_{\text {maximum }}=205$ rotations). The adopted design procedures followed the recommendations of the standards (AASHTO M323, 2017) and (AASHTO R35, 2017). The following parameters were established: rotation angle of $1.25^{\circ}$, vertical stress of $600 \mathrm{kPa}$ and rotational speed of $30 \mathrm{rpm}$. The optimum binder content was based on the following criteria: air volume (Va) in $N_{\text {initial }}$ $>11 \%$, in $N_{\text {project }}=4 \%$ and in $N_{\text {maximum }}>2 \%$; voids in mineral aggregate $(V M A) \geq 13 \%$; voids filled with asphalt (VFA) between $65 \%$ and $75 \%$; and filler/asphalt ratio between 0.8 and 1.6. The designed mixture was subjected to the modified Lottman, moisture-induced damage test (AASHTO T283, 2018).

The designed mixture had the following characteristics: binder content of $4.45 \%$, Va of $4.01 \%, V M A$ of $14.12 \%$, VFA of $71.57 \%$ and filler/asphalt ratio of 1.37 , following all the Superpave method criteria. The results of the moisture-induced damage test showed a 5\% reduction of the tensile strength, a value that is below the $30 \%$ limit set by the standard.

\subsection{Production of Prismatic Specimens}

Once the mixture was designed in the laboratory, the compaction of the asphalt mix plates was carried out, which produced prismatic specimens with the following dimensions: $38.1 \mathrm{~cm} \times 6.35 \mathrm{~cm} \times 5.08 \mathrm{~cm}$. The plate compaction was done in the compactor of the LCPC (Laboratoire Central des Ponts et Chaussées), currently called IFSTTAR (Institut Français des Sciences et Technologies des Transports, de l'Aménagement et des Réseaux). The compaction process was based on the French standard (AFNOR NF P 98-250-2, 1991). Two plates of $60 \mathrm{~cm} \times 40 \mathrm{~cm} \times 9 \mathrm{~cm}$ were compacted; five prismatic specimens were cut out from each plate with a circular saw. The (Figure 2) shows the different stages of the specimens' compaction and cutting process.

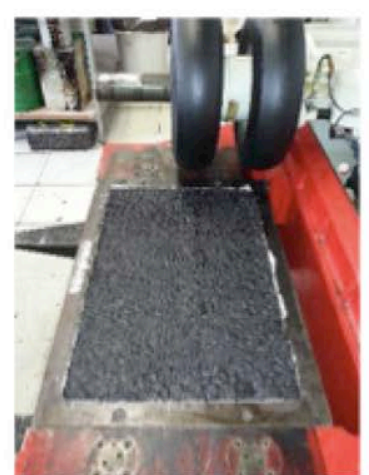

(a)

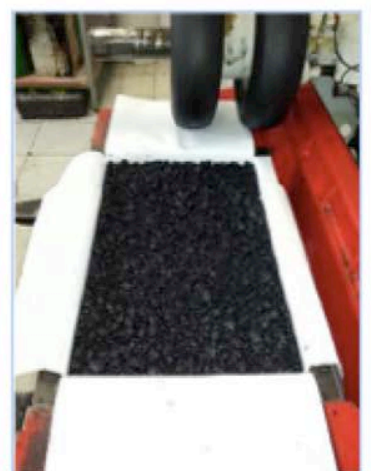

(b)

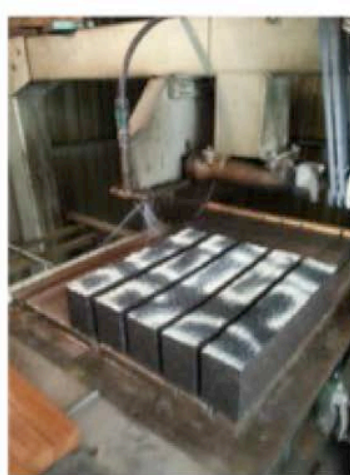

(c)

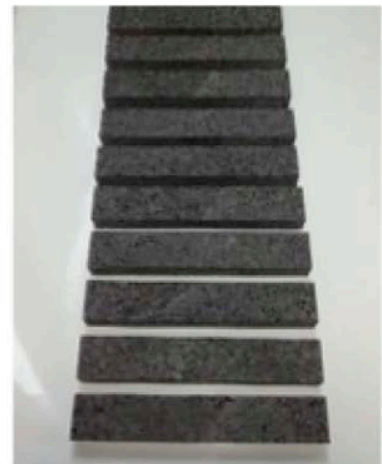

(d)

Figure 2. Specimen production: a) compaction; b) compacted plate; c) plate cutting; and d) prismatic specimens

\section{Methods}

Once the specimens were obtained, the methods used in the present study followed the structure defined below:

\subsection{Determination of the Fatigue Strength of the Asphalt Mixture}

This stage first determined the dynamic modulus of the asphalt mixture according to the recommendations of the standard (EN 12697-26, 2018) and, subsequently, the fatigue strength according to the standard (EN 12697-24, 2018); both tests were carried out in the four-point flexural fatigue machine. Eight specimens were selected out of ten, and from these eight, two were used for obtaining the dynamic modulus and six were used in the fatigue test. The dynamic modulus test applied a frequency of $10 \mathrm{~Hz}$, temperature of $20^{\circ} \mathrm{C}$, controlled deformation of $50 \mu \mathrm{m} / \mathrm{m}$ and continuous sinusoidal loading. The fatigue strength tests applied a frequency of $10 \mathrm{~Hz}$, temperature of $20^{\circ} \mathrm{C}$, continuous sinusoidal loading, controlled deformation and cracking criterion equal to $80 \%$ reduction of the initial modulus (considering that the initial modulus was established in the hundredth cycle), with the aim of enabling the application of different analysis approaches and failure criteria to the data obtained during the test.

\subsection{Development of Fatigue Models}

Following the obtainment of the fatigue test results, two fatigue cracking criteria were applied to the data: the conventional criterion and the Pronk \& Hopman criterion. The conventional failure criterion defines the failure as the moment when the modulus of the material is reduced to $50 \%$ of its initial value. As for the Pronk \& Hopman criterion, the dissipated energy rate is plotted based on the number of loading cycles; the failure point is equal to the number of cycles needed for the dissipated energy rate to deviate from a straight line tangent to the first section of the curve. According to the Pronk \& Hopman criterion, the dissipated energy rate 
Where: $E R=$ the dissipated energy rate in cycle $n=$ number of loading cycles; $w_{n}=$ dissipated energy in cycle $n$; $w_{o}=$ initial dissipated energy $\left(50^{\text {th }}\right.$ cycle $) ; \varepsilon_{o}=$ initial deformation; $\sigma_{o}=$ initial tension; $\delta_{o}=$ initial phase angle; $\varepsilon_{n}=$ deformation for cycle $n ; \sigma_{n}=$ tension for cycle $n ; \delta_{n}=$ phase angle for cycle $n$.

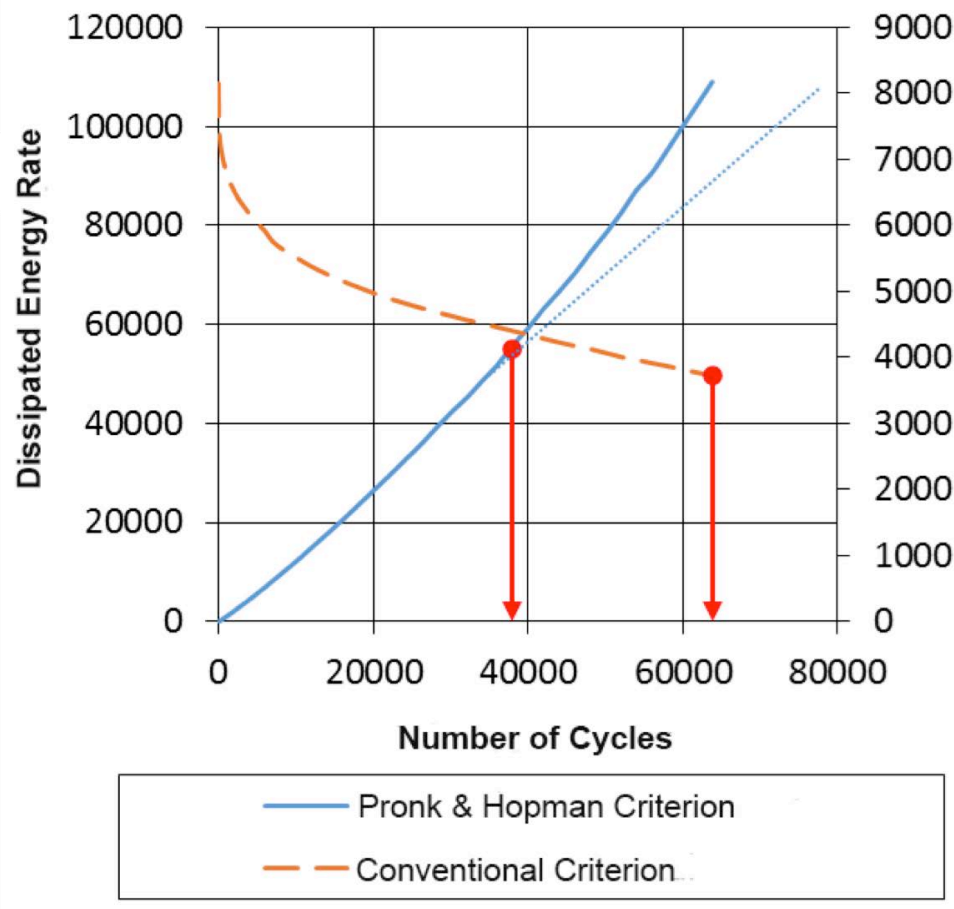

Figure 3. Representation of the conventional and Pronk \& Hopman failure criteria

After applying the failure criteria, fatigue models were developed for each criterion, with both the phenomenological and cumulative dissipated energy analysis approaches. In the phenomenological approach, the fatigue model was obtained by relating the microstrains to the number of cycles to failure, that is, by means of the Wöhler curve (Equation 2).

$N_{f}=k_{1}\left(\varepsilon_{t}\right)^{-k_{2}}$

Where: $N_{f}=$ number of cycles to failure; $\varepsilon_{t}=$ tensile microstrain; $k_{1}$ and $k_{2}=$ constants.

Concerning the cumulative dissipated energy approach, the fatigue model was developed considering the relationship between the cumulative dissipated energy and the number of cycles, both at the time of fatigue cracking; the model is shown in (Equation 3).

$N_{f}=A\left(W_{c u}\right)^{2}$

Where: $W_{c u}=$ cumulative dissipated energy in the crack; $N_{f}=$ number of cycles to failure; $Z$ y $A=$ constants.

\subsection{Fatigue Life Estimate of the Asphalt Wearing Course in the Pavement Structure}

The final stage of the study estimated the fatigue life of the asphalt wearing course in a pavement structure, using the obtained fatigue models. The objective of this stage was to show how different analysis methods and failure criteria can affect the life cycle estimate of the asphalt wearing course subjected to dynamic loads.

With this purpose in mind, a numerical simulation using the ViscoRoute software (developed by IFSTTAR/France) was carried out, which considers the viscoelastic parameters of the asphalt wearing course. The software also includes the input data of loading speed and asphalt mixture temperature. The simulation considered a standard two-wheel axle of 8.2 tons moving at a speed of 72 $\mathrm{km} / \mathrm{h}$, a speed equivalent to a testing frequency of $10 \mathrm{~Hz}$ (Chabot et al., 2010), with a distance of $32 \mathrm{~cm}$ between the wheels, load per wheel of $2050 \mathrm{kgf}$, circular contact area of $366 \mathrm{~cm}^{2}$ between the wheel and the pavement, and contact pressure of $5.6 \mathrm{kgf} / \mathrm{cm}^{2}$. A temperature of $20^{\circ} \mathrm{C}$ was considered for the asphalt wearing course, which was the same temperature used in the fatigue strength and dynamic 
modulus tests. The following characteristics were defined for the pavement structure: $18 \mathrm{~cm}$ asphalt wearing course, $18 \mathrm{~cm}$ indicates the parameters used in the numerical simulation.

Table 1. Pavement structure characteristics

\begin{tabular}{|c|c|c|c|c|}
\hline Layers & $\begin{array}{c}\text { Rheological } \\
\text { Behavior }\end{array}$ & $\begin{array}{c}\text { Modulus } \\
(\mathbf{M P a})\end{array}$ & $\begin{array}{c}\text { Phase Angle } \\
()^{\circ}\end{array}$ & $\begin{array}{c}\text { Poisson } \\
\text { (v) }\end{array}$ \\
\hline $\begin{array}{c}\text { Asphalt Wearing } \\
\text { Course } \\
\left(\mathbf{2 0} \mathbf{}^{\circ} \text { and } \mathbf{1 0 ~} \mathbf{~ H z}\right)\end{array}$ & Linear Viscoelastic & $7895^{*}$ & $24.4^{*}$ & 0.30 \\
\hline Base & Linear Elastic & 260 & - & 0.35 \\
\hline Subbase & Linear Elastic & 210 & - & 0.35 \\
\hline Subgrade & Linear Elastic & 180 & - & 0.35 \\
\hline
\end{tabular}

* Results obtained for dynamic modulus test of asphaltic mixtures $\left(20^{\circ} \mathrm{C}\right.$ y $\left.10 \mathrm{~Hz}\right)$

The output data of the ViscoRoute software was the tensile microstrain in the lower face of the asphalt wearing course at $20^{\circ} \mathrm{C}$. Subsequently, the fatigue models were used to confirm the number of cycles needed for the 8.2 ton axle to cause the fatigue cracking of the asphalt wearing course, considering the different analysis approaches and failure criteria.

With regard to the phenomenological approach, it was necessary to feed the models with the tensile microstrain obtained in the ViscoRoute software in order to estimate the fatigue cracking of the asphalt wearing course. As for the cumulative dissipated energy approach, the procedure was done differently and followed the four stages described below:

Stage 1: Development, based on fatigue strength laboratory results, of the mathematical model relating the initial dissipated energy $\left(W_{i}\right)$ with the cumulative dissipated energy $\left(W_{c u}\right)$ at the time of cracking (one model per each criterion).

Stage 2: Determination, through (Equation 4), of the initial dissipated energy $\left(W_{i}\right)$ produced in the asphalt wearing course at $20^{\circ} \mathrm{C}$ by the passing of the standard two-wheel axle of 8.2 tons at a speed of $72 \mathrm{~km} / \mathrm{h}(10 \mathrm{~Hz})$.

$W_{i}=\pi \varepsilon_{t}^{2}|E *| \operatorname{sen} \delta_{i}$

Where: $W_{i}=$ initial dissipated energy; $\varepsilon_{t}=$ tensile microstrain obtained by the ViscoRoute software; $\left|E^{*}\right|=$ dynamic modulus of the asphalt mixture at $20^{\circ} \mathrm{C}$ and $10 \mathrm{~Hz}$; $\delta_{i}=$ phase angle of the asphalt mixture at $20^{\circ} \mathrm{C}$ and $10 \mathrm{~Hz}$. Where, $\left|E^{*}\right|$ and $\delta_{i}$ were obtained in the dynamic modulus test of the asphalt mixture, see (Table 1 ).

Stage 3: Prediction of the cumulative dissipated energy $\left(W_{c u}\right)$ at the time of cracking of the asphalt wearing course, by using the initial dissipated energy $\left(W_{i}\right)$ calculated in Stage 2 and the models developed in Stage 1.

Stage 4: Estimate of the number of cycles that the 8.2 ton axle should apply to the asphalt wearing course in order to cause fatigue failure. The estimate was possible by introducing the cumulative dissipated energy $\left(W_{c u}\right)$, obtained in Stage 3 , in the fatigue models of the cumulative dissipated energy approach.

\section{Resullts and Discussion}

\subsection{Determination of the Fatigue Strength of the Asphalt Mixture}

The four-point bending machine was used for the fatigue strength test, following the recommendations of the standard (EN 12697-24, 2018). In total, six specimens were tested to failure. The (Table 2) indicates the number of cycles $\left(N_{f}\right)$ needed to reach the assessed failure criterion and the respective reduction of the initial modulus. 
Table 2. Number of cycles and reduction of the initial modulus for the different criteria

\begin{tabular}{|c|c|c|c|c|c|}
\hline \multirow[b]{2}{*}{ Specimen } & \multirow{2}{*}{$\begin{array}{l}\text { Deformation } \\
\quad\left(\times 10^{-6}\right)\end{array}$} & \multicolumn{2}{|c|}{ Conventional Criterion } & \multicolumn{2}{|c|}{ Pronk \& Hopman Criterion } \\
\hline & & $\begin{array}{l}\text { Number of } \\
\text { Cycles }\left(N_{f}\right)\end{array}$ & $\begin{array}{c}\text { Initial Modulus } \\
\text { Reduction (\%) }\end{array}$ & $\begin{array}{l}\text { Number of } \\
\text { Cycles }\left(N_{f}\right)\end{array}$ & $\begin{array}{l}\text { Initial Modulus } \\
\text { Reduction (\%) }\end{array}$ \\
\hline 1 & 150 & 204386 & 50.0 & 93685 & 35.2 \\
\hline 2 & 100 & 1719490 & 50.0 & 750855 & 36.3 \\
\hline 3 & 200 & 63775 & 50.0 & 23000 & 40.2 \\
\hline 4 & 150 & 202653 & 50.0 & 75568 & 36.8 \\
\hline 5 & 200 & 44220 & 50.0 & 16000 & 37.2 \\
\hline 6 & 100 & 1483987 & 50.0 & 678393 & 40.9 \\
\hline
\end{tabular}

In (Table 2) it is possible to verify that all cycle numbers determined by the Pronk \& Hopman criterion are more conservative than those determined by the conventional criterion. The Pronk \& Hopman criterion shows, on average, a $59.2 \%$ reduction of the number of cycles needed to reach the fatigue failure, compared with the conventional criterion; that is, this criterion considers that the asphalt material is less resistant to the fatigue phenomenon. In relation to the reduction percentage from the initial modulus, the Pronk \& Hopman criterion shows values below $50 \%$, of approximately $37.8 \%$ (variance of $5.1 \%$ ), which confirms the conservative nature of this criterion.

\subsection{Development of Fatigue Models}

The failure values obtained through the different analyzed criteria were used to build the material's fatigue models. Two analysis approaches were evaluated: the phenomenological and the cumulative dissipated energy. Two fatigue equations were built for each approach, one for each analyzed failure criterion: conventional and Pronk \& Hopman. The (Figure 4) and (Figure 5) show the resulting fatigue curves.

The (Table 3) shows the fatigue models obtained for each analysis approach and failure criterion.

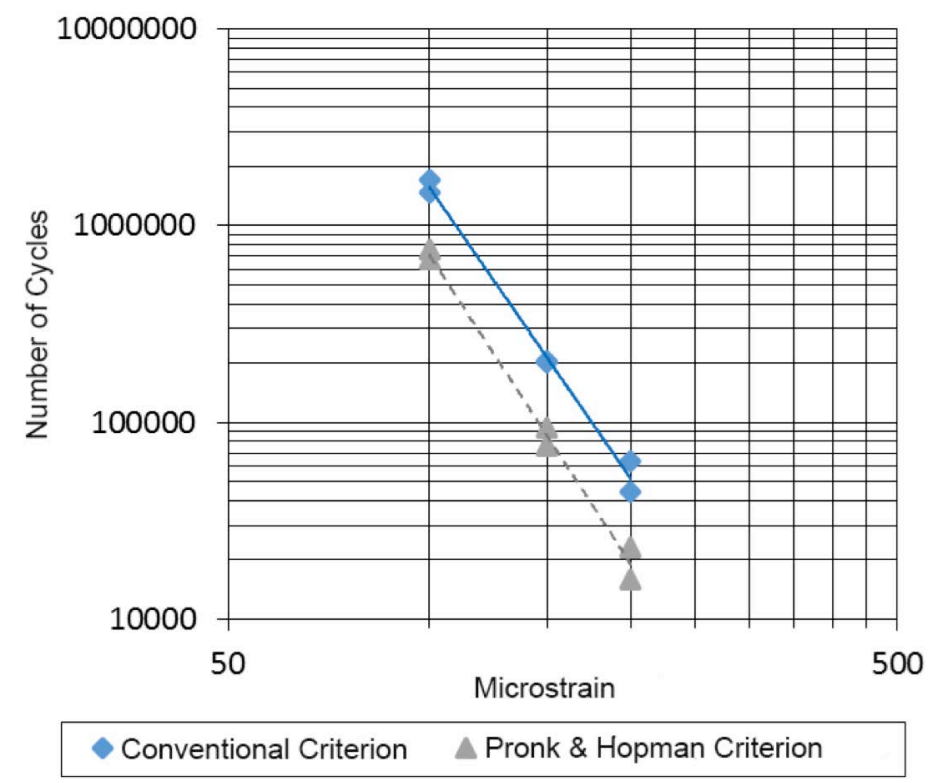

Figure 4. Fatigue curve: phenomenological approach 


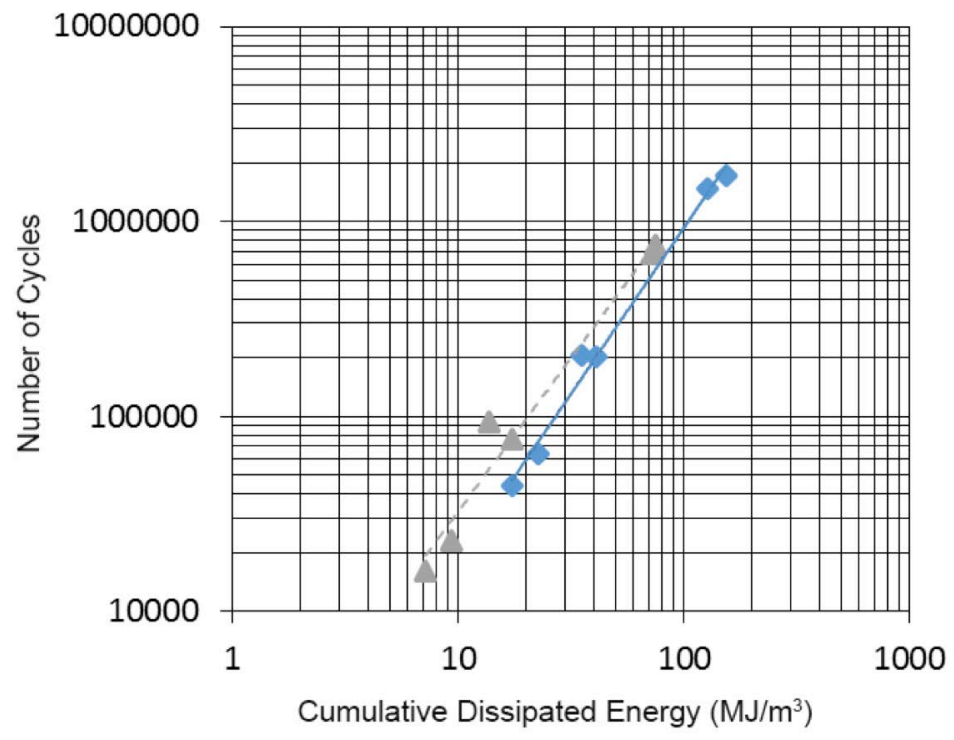

Conventional Criterion $\triangle$ Pronk \& Hopman Criterion

Figure 5. Fatigue curve: cumulative dissipated energy approach

Table 3. Fatigue models

\begin{tabular}{|c|c|c|}
\hline Criterion & Phenomenological Approach & $\begin{array}{c}\text { Cumulative Dissipated Energy } \\
\text { Approach }\end{array}$ \\
\hline Conventional & $N_{f}=1.094 \times 10^{16} \varepsilon_{t}^{-4.922}$ & $N_{f}=3.627 \times 10^{2} W_{c u}^{1.703}$ \\
\hline Pronk \& Hopman & $N_{f}=1.963 \times 10^{16} \varepsilon_{t}^{-5.221}$ & $N_{f}=8.637 \times 10^{2} W_{c u}^{1.574}$ \\
\hline
\end{tabular}

Considering the phenomenological approach, both (Figure 4) and (Figure 5), as well as (Table 3), allow verifying that the Pronk \& Hopman criterion produces a model that reflects a lower fatigue strength of the asphalt mixture, compared with the conventional criterion. This difference tends to decrease when the microstrain decreases and tends to increase when the microstrain increases; this behavior is characterized by the models' inclination. In general, concerning the amplitude of the microstrains that pavements undergo in field testing, it is evident that the Pronk \& Hopman criterion is more conservative than the conventional criterion in the phenomenological approach. When addressing the cumulative dissipated energy, the model generated by the Pronk \& Hopman criterion shows a better performance in relation to failure for the same value of cumulative dissipated energy. Nevertheless, due to the models' inclination, and for cumulative energy values higher than $840 \mathrm{MJ} / \mathrm{m}^{3}$, the conventional failure criterion tends to show a higher fatigue strength than that obtained with the Pronk \& Hopman criterion. However, it is necessary to make a numerical simulation of the pavement structure in order to specifically and clearly evaluate the influence of the failure criteria and analysis methods on the life cycle estimate of the asphalt wearing course in dealing with fatigue.

4.3 Life Cycle Estimate in the Presence of Fatigue of the Asphalt Wearing Course in the Pavement Structure

In this stage, the numerical simulation helped to determine how many times the 8.2-ton axle $\left(N_{8.2 \text { ton }}\right)$ should be applied to subject the asphalt layer to fatigue cracking; this number was determined for both analysis approaches and failure criteria. As a result of the numerical simulation, a tensile microstrain value of $70.7 \mu \mathrm{m} / \mathrm{m}$ was obtained in the lower face of the asphalt wearing course $\left(20^{\circ} \mathrm{C}\right)$, caused by the passing of the standard two-wheel axle of 8.2 tons at 72 $\mathrm{km} / \mathrm{h}(20 \mathrm{~m} / \mathrm{s})$. For this microstrain value, (Table 4) indicates the estimated life cycle of the asphalt wearing course in the presence of fatigue, according to the phenomenological approach for both failure criteria. 
Table 4. Life Cycle of the Asphalt Wearing Course in the Presence of Fatigue, according to the phenomenological approach

\begin{tabular}{|c|c|c|}
\hline Criteria & Fatigue Model & $\begin{array}{c}\boldsymbol{N}_{\mathbf{8 . 2}} \text { ton } \\
\left(\boldsymbol{\varepsilon}_{\boldsymbol{t}}=7 \mathbf{0 . 7} \boldsymbol{\mu m} / \mathbf{m}\right)\end{array}$ \\
\hline Conventional & $N_{f}=1.094 \times 10^{16} \varepsilon_{t}^{-4.922}$ & $8.633 \times 10^{6}$ \\
\hline Pronk \& Hopman & $N_{f}=1.963 \times 10^{16} \varepsilon_{t}^{-5.221}$ & $4.336 \times 10^{6}$ \\
\hline
\end{tabular}

The results of (Table 4) allow observing that the life cycle of the asphalt wearing course, estimated according to the conventional failure criterion, is higher than that estimated by the Pronk \& Hopman criterion. This could indicate that it is more conservative to consider the fatigue failure according to the dissipated energy criterion (Pronk \& Hopman). In order to match the value estimated by the Pronk \& Hopman criterion with the value estimated by the conventional criterion, the wearing course should be $2.29 \mathrm{~cm}$ thicker, which would reduce the tensile microstrain to $61.96 \mu \mathrm{m} / \mathrm{m}$ and equal the

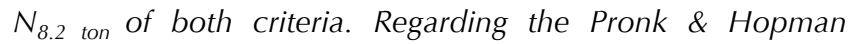
criterion, this thickness increase would correspond to a $12.72 \%$ increase above the $18-\mathrm{cm}$ thickness.

With regard to the cumulative dissipated energy approach, and in order to apply the method, the mathematical model of initial dissipated energy $\left(W_{i}\right)$ versus cumulative dissipated energy $\left(W_{c u}\right)$ was developed for each failure criteria, based on fatigue strength laboratory results, as shown in (Figure 6).

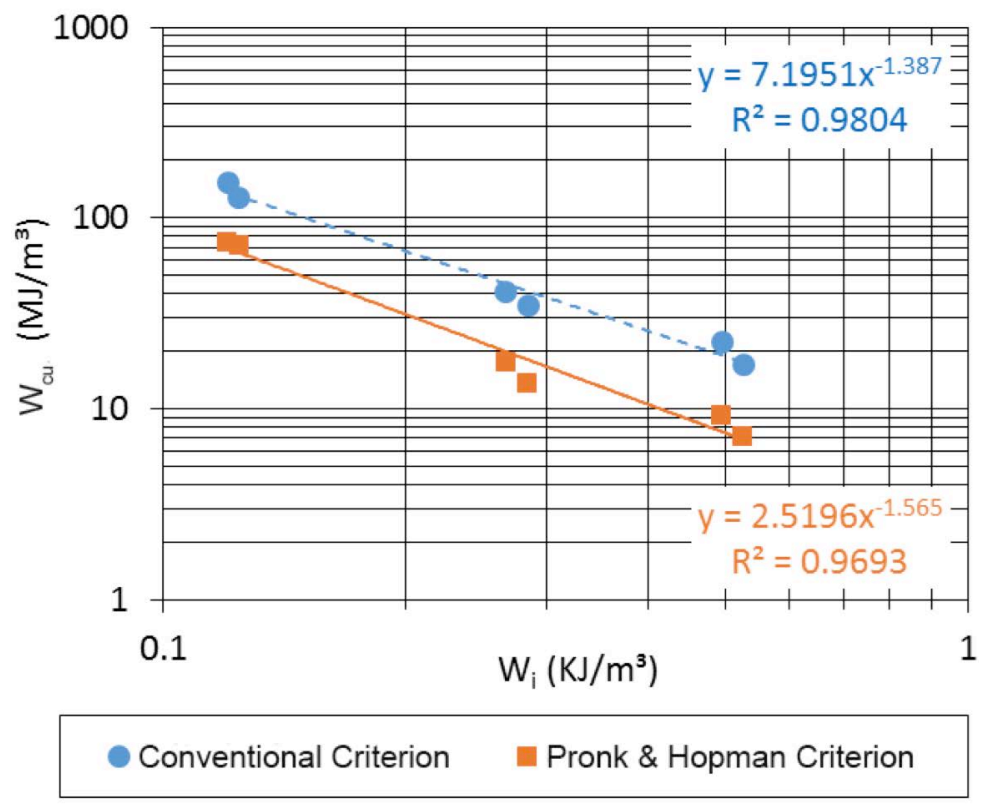

Figure 6. Ratio of the initial dissipated energy and the cumulative dissipated energy for different failure criteria

Next, and with the help of (Equation 4), the initial dissipated energy $\left(W_{i}\right)$ caused by the passing of the 8.2-ton axle over the asphalt wearing course at $20^{\circ} \mathrm{C}$, was calculated, considering a tensile microstrain of $70.7 \mu \mathrm{m} / \mathrm{m}$, dynamic modulus of $7895 \mathrm{MPa}$ and phase angle of $24.4^{\circ}$. The value of the initial dissipated energy $\left(W_{i}=0.051215 \mathrm{~kJ} / \mathrm{m}^{3}\right)$ allowed obtaining, for the models shown in (Figure 6), the value of the cumulative dissipated energy for the conventional criterion
$\left(W_{c u}=443.7 \mathrm{MJ} / \mathrm{m}^{3}\right)$ and the Pronk \& Hopman criterion $\left(W_{c u}\right.$ $\left.=263.7 \mathrm{MJ} / \mathrm{m}^{3}\right)$; these values were used in the fatigue models of the energy approach. The (Table 5) indicates the estimated life cycle of the asphalt wearing course, in the presence of fatigue, according to the cumulative dissipated energy approach and for both failure criteria. 
Table 5. Life cycle, in the presence of fatigue, of the asphalt wearing course according to the cumulative dissipated energy approach

\begin{tabular}{|c|c|c|}
\hline Criteria & Fatigue Model & $\begin{aligned} & N_{8.2 \text { ton }} \\
W_{c u}= & 443.7 \mathrm{MJ} / \mathrm{m}^{3}(\text { Conv. }) \\
W_{c u}= & 263.7 \mathrm{MJ} / \mathrm{m}^{3}(\mathrm{P} \& H)\end{aligned}$ \\
\hline Conventionall & $N_{f}=3.627 \times 10^{2} W_{c u}^{1.703}$ & $1.168 \times 10^{7}$ \\
\hline Pronk \& Hopman & $N_{f}=8.637 \times 10^{2} W_{c u}^{1.574}$ & $5.587 \times 10^{6}$ \\
\hline
\end{tabular}

According to (Table 5), and regarding the cumulative dissipated energy approach, it can be concluded that the Pronk \& Hopman criterion is more conservative than the conventional criterion. In relation to the thickness of the asphalt wearing course, if the criteria's estimated values are to match, the layer should be $20.62 \mathrm{~cm}$ thick when using the Pronk \& Hopman criterion, which means an increase of 2.62 $\mathrm{cm}$, or $14.56 \%$, in relation to the layer thickness used for the conventional criterion.

Finally, the comparison between the phenomenological and the cumulative dissipated energy approach confirms that the fatigue cracking prediction for the asphalt wearing course is $26.10 \%$ and $22.39 \%$ higher with the energy approach than with the phenomenological approach, when comparing the conventional criterion with the Pronk \& Hopman, respectively. These results reveal that the adopted failure approach and criterion will directly influence the design of the thickness of the asphalt wearing course in the pavement structure.

\section{Conclusions}

The studies undertaken in this research confirmed that the analysis approaches and failure criteria have an influence on the life cycle prediction of the wearing course in the pavement structure, in dealing with fatigue.

It was demonstrated that the Pronk \& Hopman failure criterion leads to determine a shorter life cycle of the wearing course when compared with the conventional criterion, in both studied approaches. This allows concluding that the application of the Pronk \& Hopman criterion is more conservative, while resulting in thicker wearing courses.

With regard to the performance of the wearing course in reaction to the two analysis approaches, it was demonstrated that the cumulative dissipated energy approach predicts a longer life cycle, in both failure criteria. Consequently, it is concluded that the energy approach is less conservative than the phenomenological one.

When the cumulative dissipated energy approach is used for estimating the life cycle of the wearing course, in the presence of fatigue, the results are approximately 24\% higher than those determined by the phenomenological approach. This means that, when designing the wearing course thickness, the energy approach will present smaller thicknesses than those determined by the phenomenological approach.

\section{Acknowledgements}

The authors wish to thank the Rede Temática do Asfalto/Petrobras for the investment made in the Pavement Laboratory of the Federal University of Santa Catarina and to the University itself for the support and encouragement to academic researches. 


\section{References}

AASHTO M303 (2014). American Association of State Highway and Transportation Officials. Standard specification for lime for asphalt mixtures, AASHTO Designation: M303-14.

AASHTO M320 (2017). American Association of State Highway and Transportation Officials. Standard specification for performance-graded asphalt binder, AASHTO Designation: M320-17.

AASHTO M323 (2017). American Association of State Highway and Transportation Officials. Standard specification for Superpave volumetric mix design, AASHTO Designation: M323-17.

AASHTO R35 (2017). American Association of State Highway and Transportation Officials. Standard practice for Superpave volumetric design for hot-mix asphalt (HMA), AASHTO Designation: R35-17.

AASHTO T112 (2017). American Association of State Highway and Transportation Officials. Standard method of test for clay lumps and friable particles in aggregate, AASHTO Designation: T112-17.

AASHTO T176 (2017). American Association of State Highway and Transportation Officials. Standard method of test for plastic fines in graded aggregates and soils by use of the sand equivalent test, AASHTO Designation: T176-17.

AASHTO T283 (2018). American Association of State Highway and Transportation Officials. Standard method of test for resistance of compacted asphalt mixtures to moisture-induced damage, AASHTO Designation: T283-18.

AASHTO T321 (2014). American Association of State Highway and Transportation Officials. Standard method of test for determining the fatigue life of compacted asphalt mixtures subjected to repeated flexural bending, AASHTO Designation: T321-14.

AFNOR NF P 98-250-2 (1991). Association Française de Normalisation. Essais relatifs aux chaussées - préparation des mélanges hydrocarbonés, partie 2: compactage des plaques, AFNOR Designation: 98-250-2-91.

Ameri, M.; Seif, M.; Abbasi, M.; Molayem, M.; KhavandiKhiavi, A. (2017). Fatigue performance evaluation of modified asphalt binder using of dissipated energy approach, Construction and Building Materials, 136, 184-191.

ASTM C1252 (2017). American Society for Testing and Materials. Standard test methods for uncompacted void content of fine aggregate (as influenced by particle shape, surface texture and grading), ASTM Designation: C1252-17.

ASTM C127 (2015). American Society for Testing and Materials. Standard test method for density, relative density (specific gravity), and absorption of coarse aggregate, ASTM Designation: C127-15.

ASTM C131 (2014). American Society for Testing and Materials. Standard test method for resistance to degradation of small-size coarse aggregate by abrasion and impact in the Los Angeles machine, ASTM Designation: C131-14.

ASTM C88 (2018). American Society for Testing and Materials. Standard test method for soundness of aggregates by use of sodium sulfate or magnesium sulfate, ASTM Designation: C88-18.

ASTM D36 (2014). American Society for Testing and Materials. Standard test method for softening point of bitumen (ring-and-ball apparatus), ASTM Designation: D36-14.

ASTM D4402 (2015). American Society for Testing and Materials. Standard test method for viscosity determination of asphalt at elevated temperatures using a rotational viscometer, ASTM Designation: D4402-15.

ASTM D4791 (2019). American Society for Testing and Materials. Standard test method for flat particles, elongated particles, or flat and elongated particles in coarse aggregate, ASTM Designation: D4791-19.

ASTM D5 (2013). American Society for Testing and Materials. Standard test method for penetration of bituminous materials, ASTM Designation: D5-13.

ASTM D5821 (2017). American Society for Testing and Materials. Standard test method for determining the percentage of fractured particles in coarse aggregate, ASTM Designation: D5821-17.

ASTM 176 (2017). American Society for Testing and Materials. Standard Method of Test for Plastic Fines in Graded Aggregates and Soils by Use of the Sand Equivalent Test.

Bernucci, L. B. et al., (2010). Pavimentação asfáltica: formação básica para engenheiros, Petrobras, ABEDA, Rio de Janeiro, Brasil.

Chabot, A.; Chupin, O.; Deloffre, L.; Duhamel, D. (2010). Viscoroute 2.0: a tool for the simulation of moving load effects on asphalt pavement, Road Materials and Pavements Design.

DNER-ME 084 (1995). Departamento Nacional de Estradas de Rodagem. Agregado miúdo - determinação da densidade real, DNER Designação: ME 084-95.

DNER-ME 085 (1994). Departamento Nacional de Estradas de Rodagem. Material finamente pulverizado - determinação da massa específica real, DNER Designação: ME 085-94.

Dondi, G.; Pettinari, M.; Sangiorgi, C.; Zoorob, S. E. (2013). Traditional and dissipated energy approaches to compare the 2 PB and 4PB flexural methodologies on a Warm Mix Asphalt, Construction and Building Materials, 47, 833-839.

EN 12697-24 (2018). European Standard. Bituminous mixtures - test methods for hot mix asphalt, part 24: resistance to fatigue, EN Designation: 12697-24-18.

EN 12697-26 (2018). European Standard. Bituminous mixtures - test methods for hot mix asphalt, part 26: stiffness, EN Designation: 12697-2618.

Khalid, H. A. (2000). Comparison between bending and diametral fatigue tests for bituminous materials, Materials \& Structures, 33(7), 457-465.

Melo, J. V. S. (2014). Desenvolvimento e estudo do comportamento reológico e desempenho mecânico de concretos asfálticos modificados com nanocompósitos, Tese de Doutorado, Departamento de Engenharia Civil, Universidade Federal de Santa Catarina, Florianópolis, Brasil.

Pasetto, M.; Baldo, N. (2017). Dissipated energy analysis of four-point bending test on asphalt concretes made with steel slag and RAP, International Journal of Pavement Research and Technology, 10(5), 446-453.

Shadman, M.; Ziari, H. (2017). Laboratory evaluation of fatigue life characteristics of polymer modified porous asphalt: A dissipated energy approach, Construction and Building Materials, 138, 434-440.

Sybilski, D.; Bankowski, W. (2007). Energetic method as an alternative for conventional method in fatigue life analysis of bituminous mixtures, Pavement Technology Division, Road and Bridge Research Institute, Polland.

Zeiada, W. (2012). Endurance limit for HMA based on healing phenomenon using viscoelastic continuum damage analysis, Doctorate-thesis, Arizona State University. USA. 